\title{
Dutch Disease, Informality, and Employment Intensity in Colombia
}

\author{
Ricardo Arguello \\ Universidad del Rosario, Colombia \\ Dora Jimenez \\ Universidad del Rosario / Universidad Nacional de Colombia
}

\author{
With research assistance from: \\ Edwin Torres \\ Universidad del Rosario, Colombia \\ Monica Gasca \\ Universidad del Rosario, Colombia
}

This version: May, 2015

Paper presented at the 18th Annual Conference on Global Economic Analysis, Melbourne, June, 2015 


\section{Dutch Disease, Informality, and Employment Intensity in Colombia}

\section{Abstract}

From the first half of the 2000s until 2014 the Colombian economy was under the influence of an oil and mining production and export boom that triggered the potential for Dutch disease effects. This issue was at the center of important policy (and political) debates and merits attention due to its manifested and potential impacts on several dimensions of the economy. As the boom has the potential to induce shifts in the sectorial composition of the economy, it may have significant effects on employment dynamics and on the evolution of the employment intensity, especially when the informal sector is sizable. We study the potential effects of this boom, had it extended as forecasted until 2014, before the sudden drop in international oil prices in 2015. For this, we use a recursive dynamic computable general equilibrium model, calibrated to a 2011 Social Accounting Matrix of the Colombian economy, in which activities are differentiated in terms of their formal and informal components, and suitable details are included to account for the stream of income the government receives from the booming activities. We find that resource shift and spending effects from the boom are sizeable, leading to a relative drop in exports of non-boom sectors and to shrinking output for most sectors of the economy, while employment in the formal sector and for skilled workers is favored. Furthermore, we find that the policy package designed by the Colombian government to face potential Dutch Disease effects on the economy, has limited impact for ameliorating the resource shift and spending effects.

JEL: O19; F17; C68.

Keywords: Exports, Terms of Trade, Dutch Disease, CGE modeling, Colombia

\section{Authors}

\author{
Ricardo Arguello \\ Professor, Universidad del Rosario \\ Bogota, Colombia \\ luis.arguello@urosario.edu.co
}

\author{
Dora Jimenez \\ Associate Professor, Universidad \\ Nacional de Colombia \\ Medellin, Colombia \\ djimen0@unal.edu.co
}

\section{Acknowledgements}

This research work was carried out with financial and scientific support from the Partnership for Economic Policy (PEP) (www.pep-net.org) with funding from the Department for International Development (DFID) of the United Kingdom (or UK Aid), and the Government of Canada through the International Development Research Center (IDRC). 


\section{Contents}

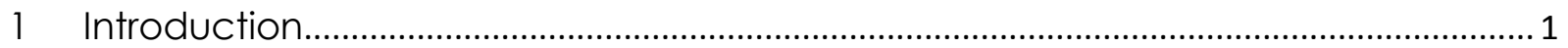

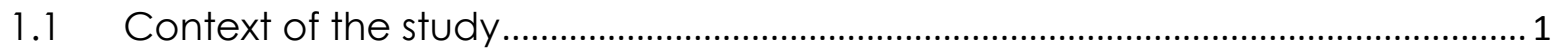

1.2 Research questions and objectives ................................................................... 4

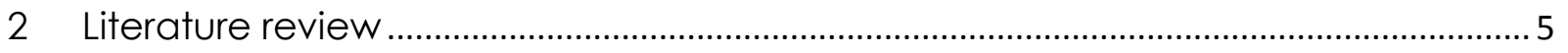

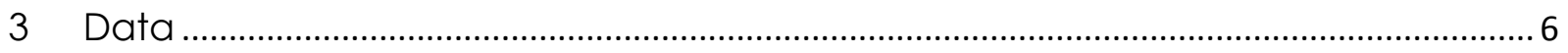

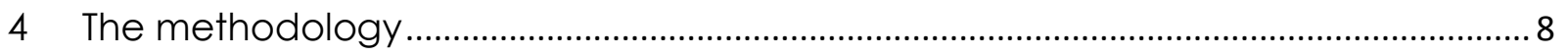

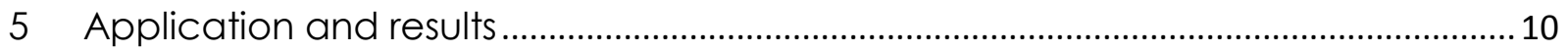

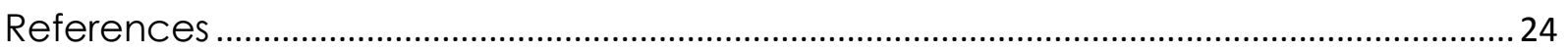

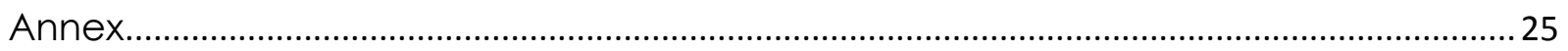

\section{List of tables}

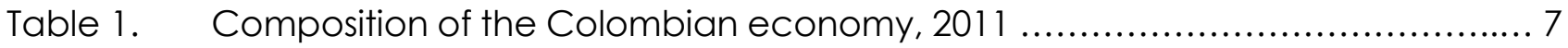

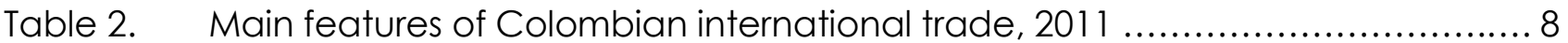

Table 3. Differences in annual average growth rates and percentage differences in 2025 for quantities imported and demanded under the boom and baseline scenarios

Table 4. Annual average compound growth rates for total quantity produced at the sector level

Table 5. Annual average compound growth rates for informal employment at the sectorial level (boom scenario)

Table 6. Annual average compound growth rates for formal employment at

Table 6. Annual average compound growth
the sectorial level (boom scenario)

Table 7. Annual average compound growth rates for informal employment at the sectorial level (FAE scenario)

$$
\text { the sectorial level (FAE scenario) }
$$

Table 8. Annual average compound growth rates for formal employment at the sectorial level (FAE scenario

\section{List of figures}

Figure 1. Sectorial Production Volume Index for the Colombian Economy (1975=100)

Figure 2. Share of mining in Colombian total exports ..................................... 2

Figure 3. Oil and coal international prices as projected in 2010 .......................... 11

Figure 4. Real GDP at basic prices under the baseline and the boom scenarios ........ 12

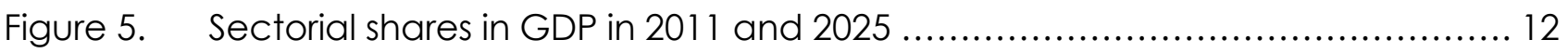


Figure 6. Commodities' shares in exports in 2025 (Baseline scenario) ........................ 13

Figure 7. Commodities' shares in exports in 2025 (Boom scenario) .......................... 13

Figure 8. Real GDP at basic prices under the baseline, boom, and FAE scenarios ....... 20 


\section{Introduction}

\subsection{Context of the study}

From the first half of the 2000s and until 2014, the Colombian economy was been under the influence of an oil and mining production and export boom that triggered the potential for Dutch Disease effects. This issue was at the center of important policy debates and merits attention due to its potential impacts on several dimensions of the economy. Among these, the likely effects of the export boom on the economy at large and on labor market dynamics. As the boom has the potential to induce shifts in the sectorial composition of the economy, it may have significant effects on employment dynamics and on the evolution of the employment intensity of the economy, especially when the informal sector is sizable.

The general context that frames this process may be described as follows. The sectorial composition of the economy, according to national accounts data, has shifted in favor of mining and other services to the detriment of agriculture, manufacturing, and public services and construction between 1983 and 2010. The share of mining in GDP increased from $2 \%$ to $8 \%$, while that of other services grew from $56 \%$ to $60 \%$. Meanwhile, the shares of agriculture, manufacturing, and public services and construction decreased from $10 \%$ to $7 \%$, from $18 \%$ to $14 \%$, and from $14 \%$ to $11 \%$, respectively.

This relatively long-term change goes in hand with the evolution of physical production along this period. As can be appreciated from figure 1, the volume index for the mining sector clearly outstrips those of the other sectors of the economy. The increase in mining production goes back to the mid-eighties with the discovery of ferronickel and gets reinforced in the mid-nineties with the discovery of relatively sizeable oil reserves. Starting from a low base and supported by the rise in international prices, the sector increases its share in total value added as mentioned above.

The increase in production is, largely, due to foreign direct investment (FDI). FDI flows into the Colombian economy have risen from near 1.5 billion dollars in 1994 to near 16.8 billion in 2013 , reaching around $7 \%$ of GDP. Of these, the share of FDI directed to the oil and mining sectors represented $12.6 \%$ in 1994, while in 2013 it reached $46.7 \%$ (with a peak of $76.4 \%$ in 2009). According to data from the Colombian Central Bank, inbound FDI destined to the oil and mining sector has added 24.6 billion dollars to the investment stock between January 2010 and the second quarter of 2013, without counting investment done by Ecopetrol, the national oil company.

Between 1991 and 2011, Colombian exports grew sevenfold (from 7.2 billion dollars to 56.9 billion), which is equivalent to an annual average compound growth rate of $11 \%$. Along this period, there were just four years in which exports showed negative growth rates, 2009 being the worst (-12.7\%). Alongside, the export share of mining has grown in a remarkable manner. As can be appreciated from the left side panel in figure 2, mining represented $33.6 \%$ of total exports in 1991 and $71 \%$ in 2011 . A breakdown of the share of mining exports by subsector, shown in the right side panel of figure 2, shows that oil accounts for the majority of them all along the 1991-2011 period. It also shows that coal is the second largest contributor to 
mining exports and that oil products is the third (ferronickel that, as mentioned, was the forerunner in the development of the Colombian mining sector, is the fourth largest).

Figure 1. Sectorial Production Volume Index for the Colombian Economy (1975 = 100)

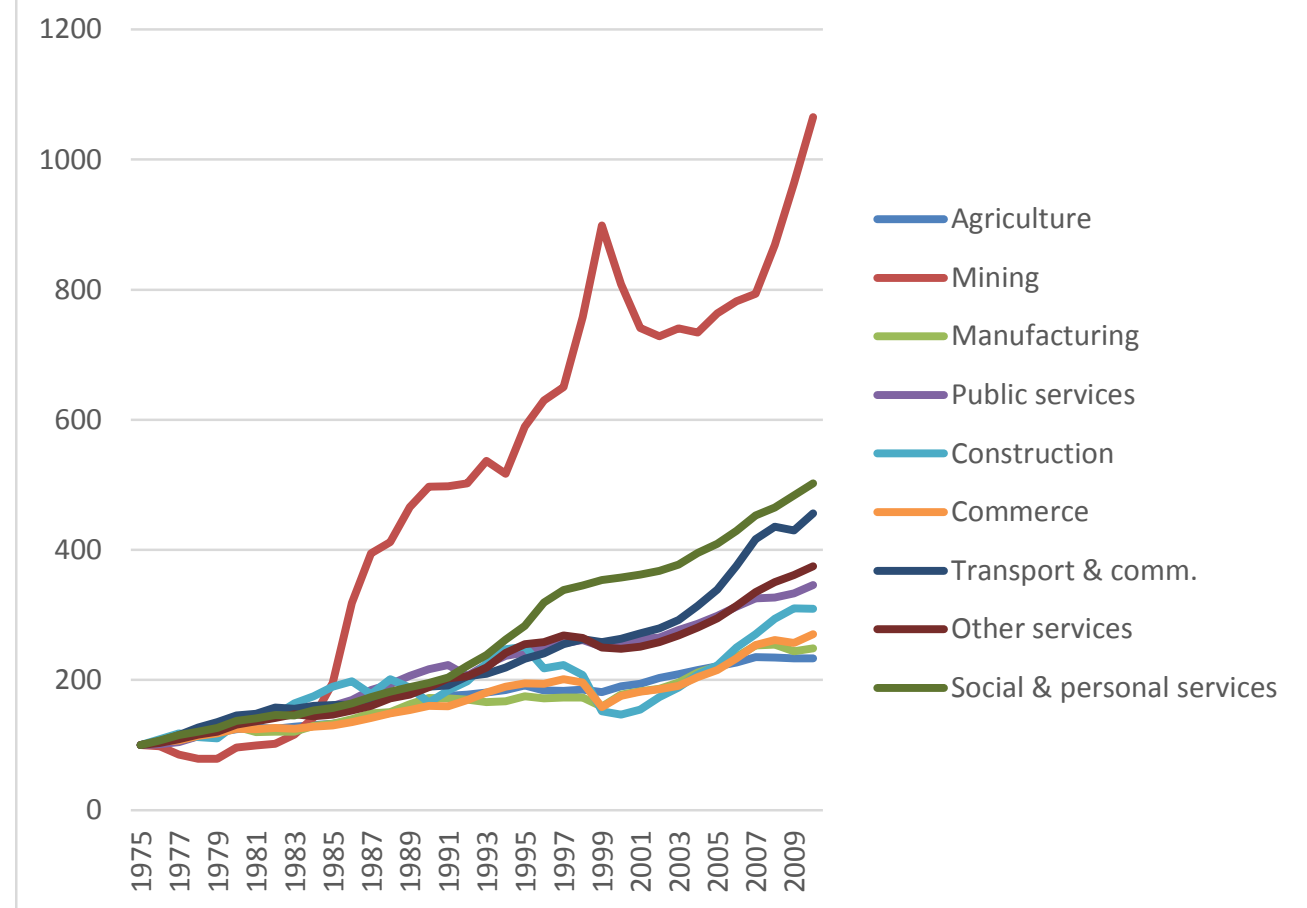

Source: Colombian National Statistical Office (DANE)

Figure 2. Share of mining in Colombian total exports

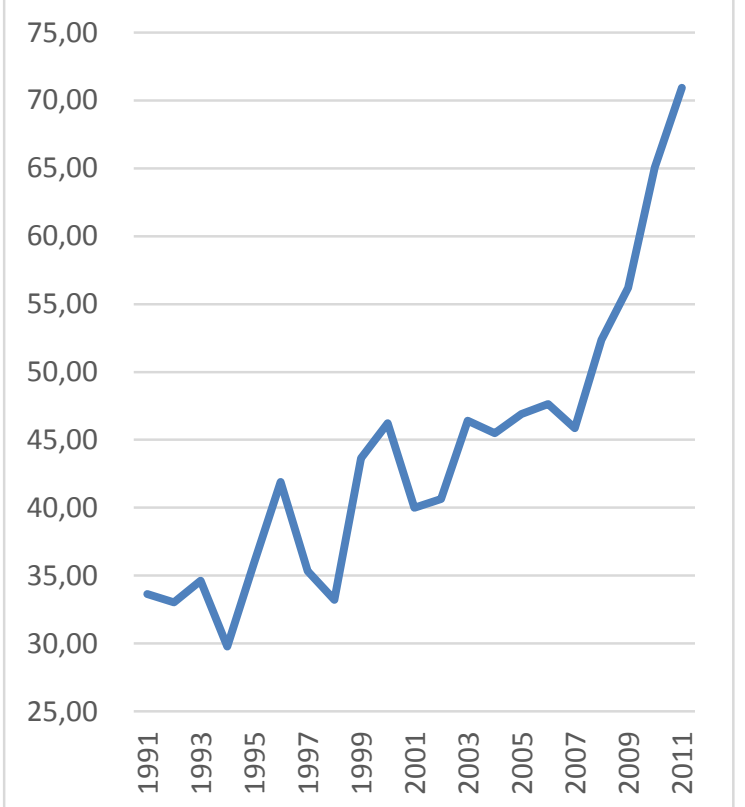

Source: Colombian National Statistical Office (DANE)

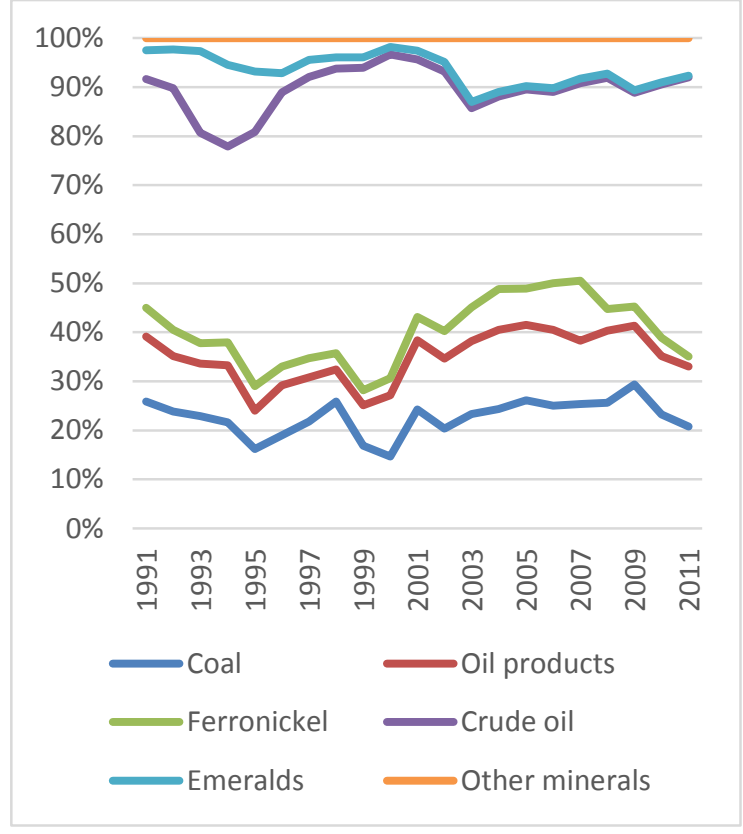

The inflow of foreign currency due to increased mining exports and incoming FDI, along with other foreign currency sources such as portfolio investments and remittances, has had an 
impact on the exchange rate. Casual observation of the behavior of the nominal exchange rate (expressed as Pesos per US Dollar) shows that between 1991 and 2003 it continuously increased at an annual compound rate of $13.4 \%$ while between 2003 and 2012 it has decreased at an annual rate of $5.1 \%$. In a similar fashion, according to the Colombian Central Bank, the real exchange rate index, either calculated based on the producer or the consumer price index, although with fluctuations, has decreased between March 2003 and December 2012 (43.1 percentage points - the decrease until October 2013 is 38.1 percentage points). That is, the most pronounced decline in the real exchange rate is contemporaneous with the acceleration in the rate of increase of the mining export share (as follows from figure 2).

The behavior of the exchange rate and of sectorial growth in recent years has ignited a debate, in policy and political circles, on the possibility that the economy may be showing symptoms of Dutch Disease. In effect, while the simple annual average growth rate for the economy was $4.6 \%$ between 2003 and 2013 , the corresponding to manufacturing was $2.9 \%$. Besides growing more slowly than the whole economy, manufacturing decreased $4.1 \%$ in $2009,1.1 \%$ in 2012 , and $1.2 \%$ in 2013. In general terms, the situation for agriculture is similar as it grew at an annual average rate of 2.2\%, with moderate decreases in 2008 and 2009 and basically no growth in 2010. In contrast, mining grew at an annual rate of $5.9 \%$ and sectors readily identifiable as predominantly non-tradable, such as construction; transport and communications; commerce, hotels, and restaurants; and financial and firm services, grew at rates ranging between $7.7 \%$ and $4.9 \%$.

Another issue of contention, not necessarily related or casted within the Dutch Disease discussion, refers to the behavior of employment. Until very recently, unemployment stayed at relatively high levels in spite of the economy showing dynamism. During the period 20032012 , the unemployment rate was $11.9 \%$ in average with moderate variation (the coefficient of variation calculated on monthly data was 0.13 ). It is only from May 2013 on that the unemployment rate has started to recede, probably as a consequence of recent fiscal reforms that reduced some surcharges associated with formal labor hiring. Between May 2013 and March 2014, the monthly average unemployment rate was $9.3 \%$.

In contrast, informal employment has been high and shows no clear sign of declining, situating around $50 \%$ of total employment, when defined based on occupational positon and social security coverage. If defined based on contribution to pensions, informality reached $67.2 \%$ of total employment during the 2000s, while representing in average $82.7 \%$ of employment in firms with less than ten workers (which account for $64 \%$ of total employment, implying that in firms with more than ten workers informality reached around $23 \%$-although with a downward trend). From a sectorial perspective, informality is higher in agriculture, commerce, construction, transport and communications, as well as in certain manufacturing activities (mainly food and beverages, apparel, and textiles).

For steering the economy away from the perils of Dutch Disease, in 2012 the government introduced legislation modifying the royalties system and creating a Savings and Stabilization Fund, administered by the Central Bank and projected to withhold an average of $24 \%$ of total royalty revenue flows between 2013 and 2022. This measure followed the implementation in 2011 of a fiscal rule, aimed at achieving fiscal sustainability by putting a 
ceiling on governmental indebtedness. Due to their recent implementation, the outcomes of these policy instruments are still relatively unknown.

\subsection{Research questions and objectives}

Given the above context, our aim is to inquire about the impact of the oil and mining production and export boom on: (i) the evolution of the productive structure of the economy, (ii) the evolution of the import-intensity of non-boom sectors and its implications for employment dynamics in general, and (iii) the evolution of the informal sector.

As for the first issue, the changes in the sectorial composition of the economy documented above and those that may ensue from further production and exports of oil and mining products, will have a potentially important effect on the structure of labor demand. In this respect, estimating what is the likely path of these changes in the short and medium run is important and instrumental for appraising the evolution of the labor market. With the appreciation of the real exchange rate, non-boom sectors tend to be affected according to their trade position. Non-boom tradable sectors are expected to be negatively affected; in the case of exportables due to erosion of their competitive position as the domestic currency appreciates, and in the case of importables due to increased competition as international prices become lower in terms of domestic currency.

On the contrary, non-boom non-tradable sectors are expected to be positively affected, as higher national income translates in increased demand for them and their prices increase. In the medium run, both the boom sector and the non-tradables sector should increase production at the expense of the rest of the economy as relative prices favor them. This translates in changes in employment levels according, among other factors, to the easiness of factor mobility, relative labor intensiveness across activities, potential adjustments in technology use, and the cross effect between formal and informal activities within each sector.

Therefore, estimation of the impact of Dutch disease economics on employment is not straightforward, especially if it is taken into account that activities decompose in formal and informal sub-activities. As informality tends to concentrate in the non-tradables sector, we can expect the informal sector to boost if the formal part of the non-tradables sector does not absorb (and formalize) informal workers in an accelerated manner, so that it not only hires workers expelled from the non-boom tradable sector but also informal workers from the non-tradables sector. Therefore, the likely effect of Dutch disease economics on the informal sector is mainly an empirical question. From a policy perspective it is clearly relevant to know if the informal sector is bound to further increase in size (i.e. number of workers), what is the likely behavior of income generation within the sector, and how it translates into households' income.

For these purposes, we use a recursive dynamic computable general equilibrium model to run three types of simulations. In the first, we build the baseline scenario, that is, we trace the expected behavior of the economy, arising from its 2011 equilibrium and growing at the population growth rate. In the second, we simulate the behavior of the economy had international oil and coal prices behaved as projected before the price collapse of 2015. In 
the third, we examine the effects of a set of policy instruments that the government has recently put in place, as briefly described above.

\section{Literature review}

Dutch disease economics has received broad attention in the literature. It has been associated to significant medium term income increases arising from an export boom or enhanced foreign capital inflows, including remittances, international aid, and foreign direct investment. The classic treatment of the subject in Corden and Neary (1982) distinguishes two effects: a spending effect and a resource movement effect. The first occurs as a result of the increased real income accruing from the boom, which, provided tradable and non-tradable goods are not inferior, translates in greater demand for both. Short run effects from this increase in demand, lead to higher prices for non-tradables and larger imports, and a change in relative prices of non-tradables with respect to tradables, implying appreciation of the real exchange rate (which in turn negatively impinges upon the competitiveness of non-boom export sectors).

Higher prices in the non-tradables sector and increased activity in the boom sector, induces reallocation of resources from the rest of the economy. This reallocation has general equilibrium effects that are not obvious and depend mainly on consumer behavior and factor mobility.

In its analysis of one of the several coffee booms of the Colombian economy, Edwards (1985) found that higher coffee prices led to an increase in reserves and to a higher rate of money supply. As a consequence, the inflation rate increased and the dynamics of the nominal exchange rate led to real exchange rate appreciation and loss of competitiveness for tradables other than coffee. If, under these circumstances, the government increases its deficit and finances it (even partially) with foreign borrowing, pressure on the real exchange rate increases and a magnification effect ensues. As pointed out by the Colombian Ministry of Finance (2011), the Colombian experience in the management of export booms has not been very fortunate and the economy has experienced growth deceleration in the aftermath of these booms.

There is robust evidence that increases in the terms of trade lead to a real exchange rate appreciation in countries rich in natural resources, as illustrated for example in Spatafora and Warner (1995). In contrast, evidence on a deindustrialization process seems to be less conclusive. For instance, Sala-i-Martin and Subramanian (2003) finds no clear cut effects in this direction, while Ismail (2010) claims that a 10\% increase in oil income produces an average $3.4 \%$ drop in industrial value added. Also, deindustrialization tends to be higher in economies that are more open to capital flows and have less capital intensive manufacturing sectors.

As happens with deindustrialization, evidence on the long term consequences of the Dutch disease is blurred. Sachs and Warner (2001) argues that natural resources abundance has a strong negative effect on economic growth, leading to the infamous "curse of natural resources". Lederman and Maloney (2008) founds a positive effect of natural resources abundance on long term growth. Collier and Goderis (2007), using panel data, tries to 
reconcile these opposite views; it concludes that price booms have a short term positive impact on growth and that economies with poor governance and natural resource enclaves (like oil and mining) show significantly negative long term growth effects. Treviño (2011) uses a heuristic approach for appraising the CEMAC region economies, finding that in the oil rich ones there is indeed real exchange rate appreciation and factor reallocation but that there is no evidence of a resource curse as oil abundance does not seem correlated with long term performance. Magud and Sosa (2010) argues that there is no mechanism in the literature by which Dutch disease reduces long term growth.

Consistent with the above discussion, we take the view (with Magud and Sousa, 2010) that, from a policy making point of view what is perhaps more relevant is to determine if the appreciation is driven by a permanent (structural) change and then steer the economy away from overshooting, overheating, and the rise of macro imbalances that may prove unsustainable. However, determining whether or not the economy is facing a permanent change is a daunting task and mistakes could be costly. In any case, the short and medium run effects of real exchange rate appreciation, where a host of potentially undesirable consequences of Dutch disease economics concentrate, should be assessed and hopefully addressed. While our research cannot help in determining the nature of the shock behind the Dutch disease, it can certainly contribute to the appraisal of its consequences on the three fronts mentioned above and to usefully inform policy making in the corresponding dimensions.

There is only one piece of work that we are aware of (and is publicly available) that investigates the potential effects of Dutch disease in Colombia and may be useful for appraising its effects on the real economy. The reference is to Rojas and Forero (2011) which examines the macroeconomic impact of an oil boom on the Colombian economy and, among other issues, explores alternative scenarios for facing the boom. The paper uses a recursive dynamic CGE model to simulate four scenarios: (i) short run consumption of income from the boom, (ii) establishment of an external fund, (iii) investment in infrastructure, and (iv) phase off of distorting taxes (the boom's income substituting for lost fiscal revenue). As follows, the focus of this work differs markedly from ours. While it explores best courses of action for the government for using the revenue windfall, with growth as the leitmotif of intervention, our work centers around the potential impact of the boom and policies tailored to manage it on labor market dynamics in the sense depicted above.

\section{Data}

We built a 2011 SAM for Colombia to run the CGE model and the simulations. Activities are distinguished by their formal or informal character and demand formal and informal labor according to it. Only formal activities pay taxes on production and only commodities produced by formal activities pay indirect taxes. The oil and mining sectors use capital and natural resources as composite capital, while the rest of the economy only uses capital. Rents from natural resources accrue to the government as royalties and the national oil company pays dividends to the government, who also receives dividend payments from other state companies belonging to the rest of the economy. 
It is useful to employ the macro data contained in the SAM to provide a summary of the Colombian economy that allows for a better understanding of its structure and some of the features relevant for our study. In this regard, Table 1 provides a broad picture of the Colombian economy, which is of a size similar to that of Denmark but with a population almost nine times larger.

Table1. Composition of the Colombian economy, 2011

\begin{tabular}{|c|c|c|c|c|c|c|c|}
\hline \multirow[b]{2}{*}{ Sector } & \multirow[b]{2}{*}{ Type } & \multicolumn{5}{|c|}{ Sectorial Share in: } & \multirow{2}{*}{$\begin{array}{c}\text { Capital- } \\
\text { Labor } \\
\text { ratio }\end{array}$} \\
\hline & & $\begin{array}{l}\text { Value } \\
\text { Added }\end{array}$ & $\begin{array}{c}\text { Total } \\
\text { Employment }\end{array}$ & $\begin{array}{l}\text { Unskilled } \\
\text { Labor }\end{array}$ & $\begin{array}{l}\text { Skilled } \\
\text { Labor }\end{array}$ & Capital & \\
\hline \multirow{2}{*}{ Agriculture } & Formal & 1.6 & 2.3 & 4.4 & 1.4 & 1.0 & 0.4 \\
\hline & Informal & 5.2 & 8.2 & 22.9 & 2.0 & 2.0 & 0.2 \\
\hline \multirow{2}{*}{ Coal } & Formal & 1.9 & 0.5 & 0.4 & 0.5 & 3.2 & 5.5 \\
\hline & Informal & 0.0 & 0.1 & 0.1 & 0.0 & 0.0 & 0.3 \\
\hline Oil & Formal & 9.1 & 1.1 & 0.3 & 1.5 & 16.7 & 12.0 \\
\hline \multirow{2}{*}{ Metals } & Formal & 0.4 & 0.2 & 0.3 & 0.1 & 0.5 & 2.5 \\
\hline & Informal & 0.3 & 0.4 & 1.1 & 0.1 & 0.4 & 0.8 \\
\hline \multirow{2}{*}{ Non-metals } & Formal & 0.2 & 0.2 & 0.3 & 0.2 & 0.1 & 0.4 \\
\hline & Informal & 0.2 & 0.2 & 0.7 & 0.0 & 0.1 & 0.4 \\
\hline \multirow{2}{*}{ Industry } & Formal & 8.3 & 7.4 & 3.4 & 9.0 & 9.4 & 1.0 \\
\hline & Informal & 2.4 & 3.0 & 4.7 & 2.3 & 1.8 & 0.5 \\
\hline Refinery & Formal & 2.8 & 0.2 & 0.1 & 0.3 & 6.2 & 23.3 \\
\hline \multirow{2}{*}{ Services } & Formal & 37.3 & 35.8 & 16.5 & 43.9 & 38.8 & 0.9 \\
\hline & Informal & 23.8 & 30.6 & 43.8 & 25.0 & 17.5 & 0.5 \\
\hline Pub. Admin. & Formal & 6.35 & 9.87 & 1.05 & 13.58 & 2.26 & 0.18 \\
\hline
\end{tabular}

Source: SAM 2011

Given the sectorization of the economy we are using, $61 \%$ of value added generates from the services sector, $13.5 \%$ comes from industry and refinery, $12.2 \%$ from the extractive sector, and $6.8 \%$ from. In total $68.1 \%$ of value added arises from formal activities, while the remaining $31.9 \%$ from informal activities. The sectors with the largest informal component are agriculture (76\%), metallic minerals (49\%), non-metallic minerals (48\%), and services $(39 \%)$, while the least informal are oil, refinery, and public administration, which are completely formal, and coal (98\% formal).

The distribution of employment grossly follows value added lines: $66.4 \%$ of total employment belongs to the services sector, $10.4 \%$ to industry, $9.9 \%$ to public administration, and $10.5 \%$ to agriculture. Unskilled labor concentrates in the services sector (60.3\%), agriculture (27.3\%), and industry (8.1\%). The figure corresponding to agriculture indicates a high overrepresentation of unskilled labor in this sector with respect to value added. Skilled labor is mostly employed in the services sector (68.9\%), the public administration sector (13.6\%), and the industry sector (11.3\%).

With respect to capital, its use is conspicuous in the services sector (56.4\%), the oil sector (16.7\%), the industry sector (11.2\%), and the refinery sector (6.2\%). The cases of oil and refinery show a higher than proportional use of capital with respect to their share in value added suggesting a high capital-labor ratio. This feature is confirmed in the last column of Table 1 where we report the sectorial capital-labor ratios. The highest ratios are found for 
the refinery sector (23.3), the oil sector (12), the coal sector (4.9), and the metallic minerals sector (1.3).

As for international trade, the trade dependency ratio ${ }^{\prime}$ of the Colombian economy was $37 \%$ in 2011, a year during which it sustained a negative trade balance equivalent to $1.2 \%$ of GDP. As shown in Table 2, the share of products related to the extractive sectors account for $53.2 \%$ of total exports, followed by industrial exports (29.3\%), and refinery exports (9.3\%). On the import side, the majority of trade is in industrial goods (19\%), followed by services (9.1\%), and refinery products (7.4\%). The set of products with the greatest export orientation, as measured by the export coefficient ${ }^{2}$ are coal, oil, metals, and refinery products, all originated in the extractive sectors. Lastly, as shown in the last column of Table 2, the greatest penetration of imports, as measured by the import penetration ratio ${ }^{3}$, belong to industrial and refinery products.

Table 2. Main features of Colombian international trade, 2011

\begin{tabular}{|l|c|c|c|c|}
\hline \multirow{2}{*}{ Products } & \multicolumn{2}{|c|}{ Share in total: } & $\begin{array}{c}\text { Export } \\
\text { Coefficient }\end{array}$ & $\begin{array}{c}\text { Import } \\
\text { Penetration }\end{array}$ \\
\cline { 2 - 3 } & Exports & Imports & 0.07 & 0.08 \\
\hline Agriculture & 3.7 & 4.2 & 0.95 & 0.01 \\
\hline Coal & 12.2 & 0.0 & 0.71 & 0.00 \\
\hline Oil & 39.1 & 0.0 & 0.30 & 0.01 \\
\hline Metals & 1.6 & 0.0 & 0.09 & 0.07 \\
\hline Non-metals & 0.3 & 0.2 & 0.11 & 0.26 \\
\hline Industry & 29.3 & 79.0 & 0.26 & 0.23 \\
\hline Refinery & 9.3 & 7.4 & 0.01 & 0.02 \\
\hline Services & 4.5 & 9.1 & & \\
\hline
\end{tabular}

Source: Macro SAM 2011

As follows from the above, the economy shows a relatively important dependence on the extractive sectors, which in spite of having a sizeable but not overwhelmingly high share in value added, have a very high share in exports. This is reflected in the rising importance of governmental income originating in these sectors, reaching almost $11 \%$ of total government revenue, of which $63 \%$ correspond to royalties and $37 \%$ to dividends accruing from the national oil company. In the face of potential Dutch Disease effects, sectors highly dependent on products (different from oil, coal, and minerals) with high export coefficients or high import penetration ratios are likely to be negatively affected to the detriment of the economy in the longer run, provided the extractive products export boom is not of a structural (permanent) nature.

\section{The methodology}

As mentioned, we use a dynamic recursive computable general equilibrium model (CGE) for our analysis. CGEs are particularly well suited for the task at hand since they have the capacity of taking into account second round effects of the external shocks on the

1 Total trade as a percentage of GDP.

2 Exports as a percentage of domestic production.

3 Imports as a percentage of domestic absorption. 
economy, and to provide sectorial and other economic detail useful for economic analysis and policy making. In particular, we will use the single country, recursive dynamic version of the Partnership for Economic Policy (PEP) model, fully documented in Decaluwé et al (2012). The model extends to multiple periods the single-period PEP-1-1 model, through linking successive periods by means of variables that are inherited from the previous one and are transmitted by a set of "dynamic equations". The model belongs to the neoclassical tradition, in a perfect competition setting, and agents' behavior is drawn from optimization problems. As the model has a thorough documentation, we focus here on the features that distinguish our version of the model from the original one.

As the distinction between formal and informal sectors is central to our objectives, we have both types of activities in the model. While the basic layout of their production function is similar, they differ in two main respects. First, informal activities produce to supply the domestic market; that is, they do not export. Second, informal activities do not pay taxes. The basic structure of both activity types involves a Leontief top nest mixing value added and aggregate intermediate consumption, while in the second nest value added is generated as a constant elasticity of substitution (CES) combination of composite labor and capital. While there is only one type of capital for non-oil and non-mineral extraction activities in the model, oil and mining activities make use of two types of capital: capital and natural resources. On the other hand, composite labor is a CES blend of skilled and unskilled labor, which is of the informal type in the case of an informal activity and of the formal type in the case of a formal activity. Lastly, aggregate intermediate consumption is represented, in the second nest, as a Leontief combination of composite goods.

Given the structure of supply, the implied structure from the demand side assumes imperfect substitution between products produced by formal and informal activities (through a CES aggregator). While informal products come only from domestic (informal) activities, formal products come from domestic formal activities and from the Rest of the World (as imports), once again as imperfect substitutes (CES). Imported products are assumed formal, as are exported products. Therefore, both, formal and informal activities, demand composite goods for intermediate consumption and this composition is made up of formal domestic and imported products, on one side, and of informal products, on the other. The same is true for other sources of demand (households, government, and investment). Taxes on products are levied only on products originated in formal activities while those coming from informal activities do not pay taxes.

As follows from the production structures depicted above, we assume the labor market is segmented in a formal and an informal sector. However, the distinction between formality and informality has nothing to do with the intrinsic characteristics of workers, in the sense that there are both skilled and unskilled workers in the two segments and what determines their formal or informal character is simply the type of activity that hires them. While equilibrium in the formal segment is attained through equalization of demand for formal employment and its supply (after deducting labor mobility to the informal sector and unemployment), in the informal segment it is achieved through equalization of demand and total supply (i.e. supply of informal labor plus labor coming from the formal segment). Mobility between the two segments follows a Harris and Todaro (1970) mechanism: mobility stops when the informal wage "equates" the expected wage in the formal sector. Lastly, there is unemployment in the formal segment with real wage downward rigidity, and full 
employment in the informal segment, under fully adjustable wages. However, there is the possibility that market clearing in the formal segment arises through wages. In this case, the unemployment level in the formal segment hits its (calibrated) minimum, labor supply becomes perfectly inelastic, and wages clear the market (in which case there is no labor mobility between the formal and informal segments). This is achieved by using a complementary-slackness condition.

Also, a set of features is added to the model for several purposes. First, we isolate rents accruing to the government from natural resources either in the form of royalties or dividends received from the national oil company. The calculation of dividends is endogenous to the model and the rate at which they are generated depends upon the behavior of international prices. ${ }^{4}$ Second, we take into account that investment in oil and mining production is not only dependent on their relative rental rates but also, and mostly, on Foreign Direct Investment (FDI). As a consequence, we single out FDI in the oil and mining sectors and let the market assign new investment only for the remaining part of foreign savings (plus domestic savings), so total investment in these sectors is composed of competitively assigned new capital plus FDI. This feature of the model allows for exogenously shocking FDI in case it is deemed relevant. Third, we model the administration of oil and mining royalties ensuing to the government in a way that allows simulating the implementation of the Savings and Stabilization Fund (FAE for its Spanish language acronym), a policy measure undertaken by the government to help avoid potential Dutch Disease effects on the economy. ${ }^{5}$

In the appendix, we provide a full account of the relevant equations of the model.

\section{$5 \quad$ Application and results}

With the model described above, we run three sets of simulations. One corresponding to the baseline, tracing the behavior of the economy along a 15 year-span, in which the economy is assumed to grow at the steady state rate. ${ }^{6}$ A second one, in which oil and coal international prices grow at the rates forecasted by the World Bank in 2013. In a third simulation, we add the implementation of the FAE by the Colombian government.

In all cases we use the following closure rules. The nominal exchange rate is the numeraire, foreign savings is exogenous, real current government expenditure in goods and services is exogenous, foreign direct investment in the oil and coal sectors is exogenous, and investment is savings driven. This way, in the face of changes in international prices, the real exchange rate (defined as the nominal exchange rate over the price index for domestically produce goods) varies in order to clear the current account allowing for capturing potential Dutch Disease effects.

\footnotetext{
${ }^{4}$ We use an elasticity calculated by Olivera et al (2013).

5 There is domestic legislation establishing that oil exports must proceed only after fulfilling domestic demand by the refinery industry. As Colombia does not register crude oil imports and the selling price to refineries is tied to a formula linked to the international price, there is no need to explicitly model this characteristic of the domestic oil market.

6 The population growth rate (1.3\% per year).
} 
Against the picture depicted in the baseline scenario, in the second one (boom scenario) the international prices of oil and coal vary according to price forecasts issued in 2010, which were the expected prices before which the Colombian government projected the behavior of the economy and designed the policy measures that we simulate in the third scenario. The expected behavior of prices is depicted in figure 3, which in the case of oil implies an increase of near 60\% with respect to the base year (2011) by 2025.

Figure 3. Oil and coal international prices as projected in 2010

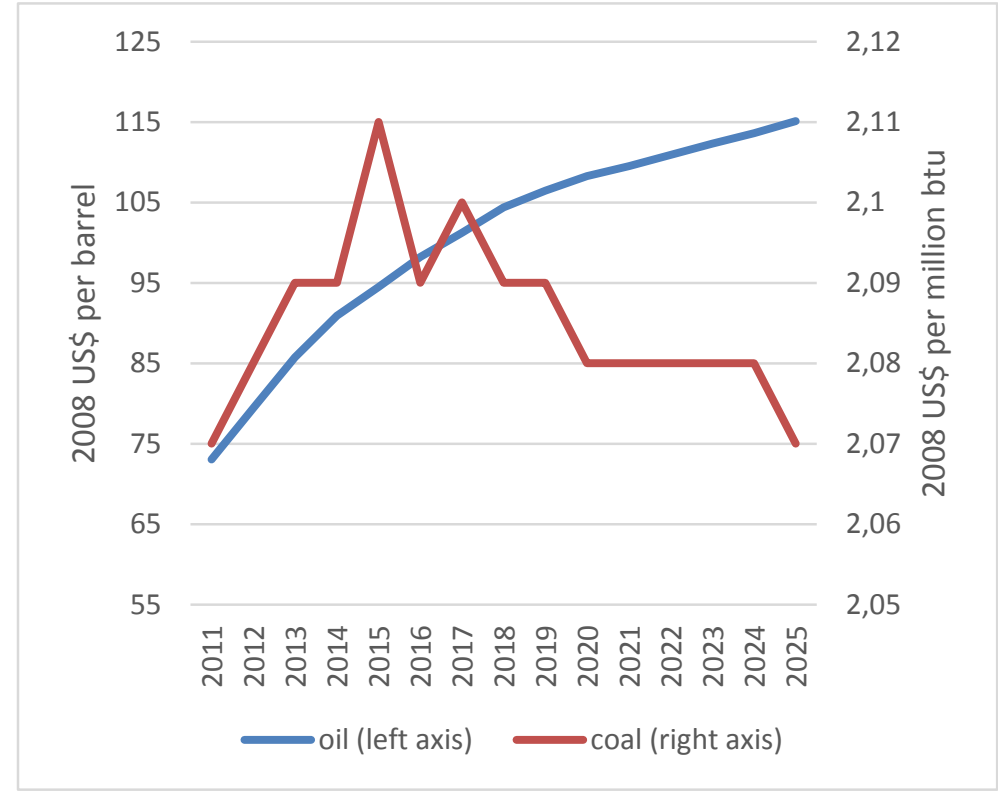

Source: US Energy Information Administration

Real GDP at basic prices grows under the boom scenario at an annual compound rate of $1.8 \%$, almost 0.4 percentage points per year above the implied steady state rate. As follows from figure 4, this average difference translates in real GDP levels that start $0.4 \%$ above baseline levels in 2012, systematically increasing to reach a 5.2\% difference in 2025 .

To trace back the forces behind the performance of the economy under the boom scenario, we can look at the sectorial contribution to GDP. Figure 5 shows the sectorial shares in GDP in the base year and in 2025 for the boom scenario. As can be appreciated, the only two sectors that increase their shares in GDP are oil and formal industry, the former by 3.8 percentage points, and the latter by 1.8 percentage points. With the exception of informal coal, the rest of sectors show decreases in their contributions to GDP, the largest amounting to 2.4 percentage points, corresponding to informal services and the smallest amounting to 0.05 percentage points in the case of informal minerals (metallic and nonmetallic dumped together). This way, the share of the extractive sectors (oil and mining in general) in GDP increases from 12.2\% in 2011 to $15.5 \%$ in 2025. 
Figure 4. Real GDP at basic prices under the baseline and the boom scenarios

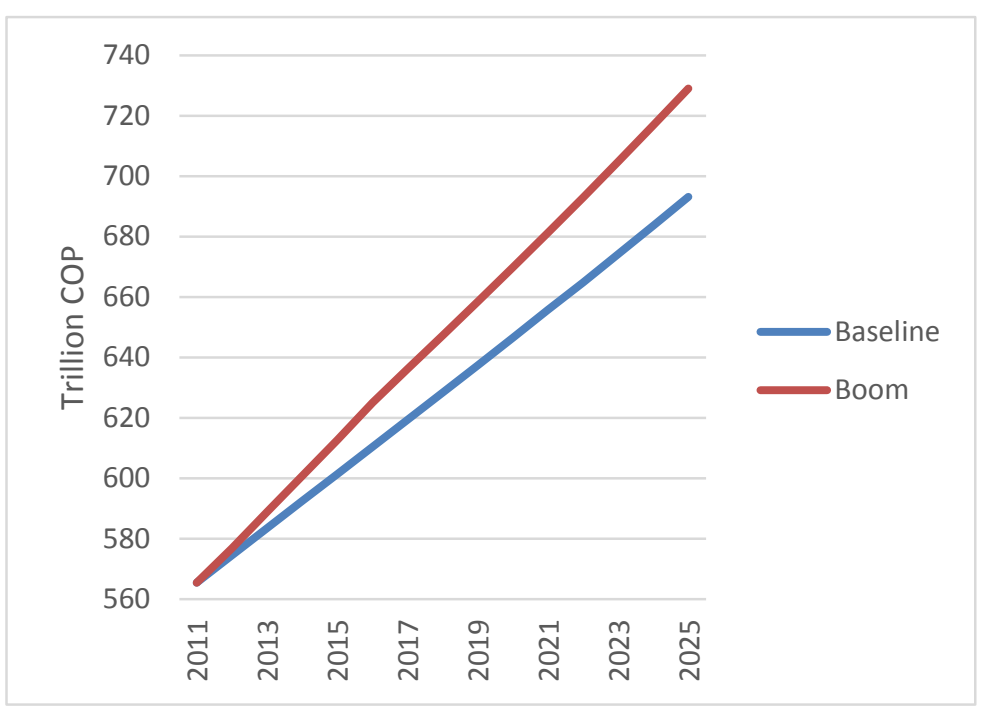

Source: CGE model simulations

Figure 5. Sectorial shares in GDP in 2011 and 2025

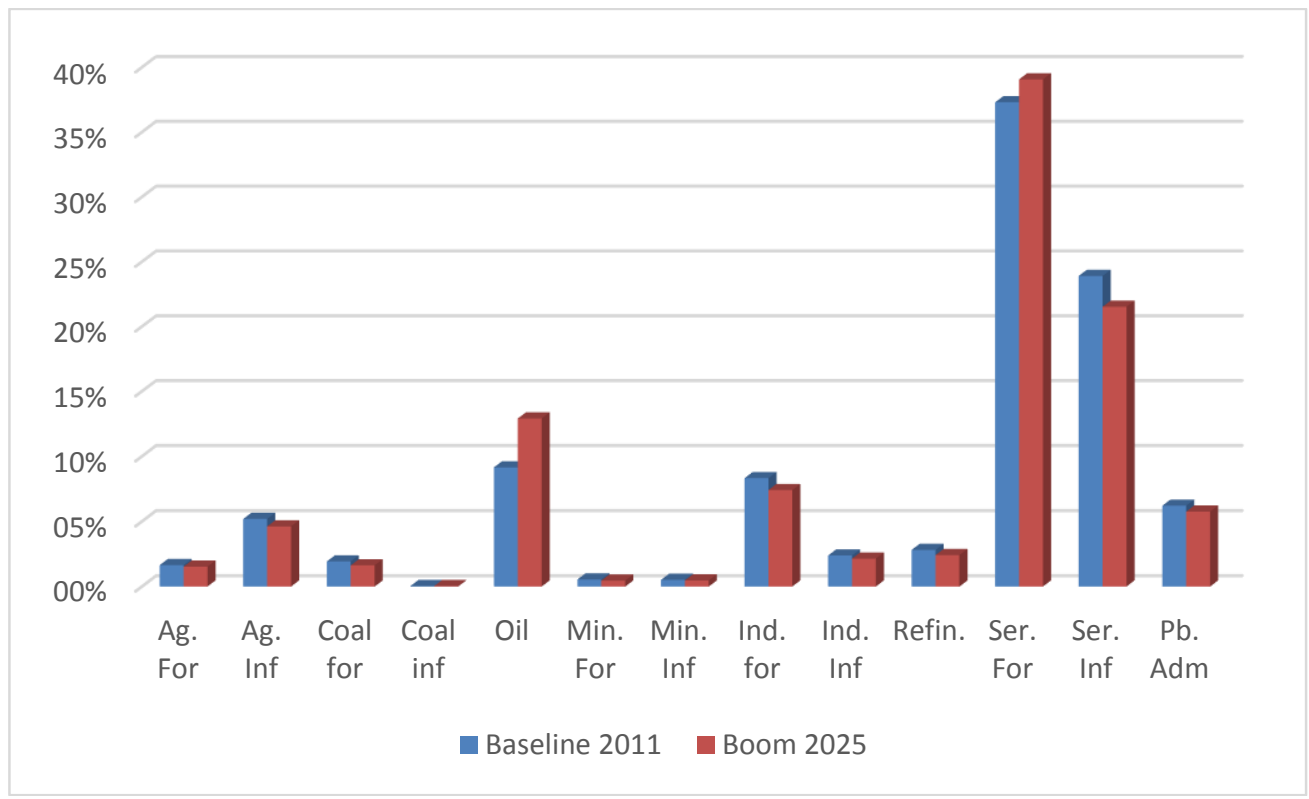

Source: CGE model simulations

As the force that causes this behavior is the change in the international prices for oil and coal, it is useful to examine the behavior of international trade. As could be expected, in this case the changes that occur in exported values between the base year and 2025 are much more pronounced that those corresponding to sectorial shares in GDP. As illustrated in figures 6 and 7 , there are important changes in the composition of exports, the most important being the increase in the share of oil exports, that goes from $40 \%$ of total exports (as expected for 2025 under the baseline) to $57 \%$ (for the same year under the boom scenario). With these changes, the share in total exports of commodities coming from extractive activities rises from $53 \%$ in 2011 to $68 \%$ in 2025 . 
Figure 6. Commodities' shares in exports in 2025 (Baseline scenario)

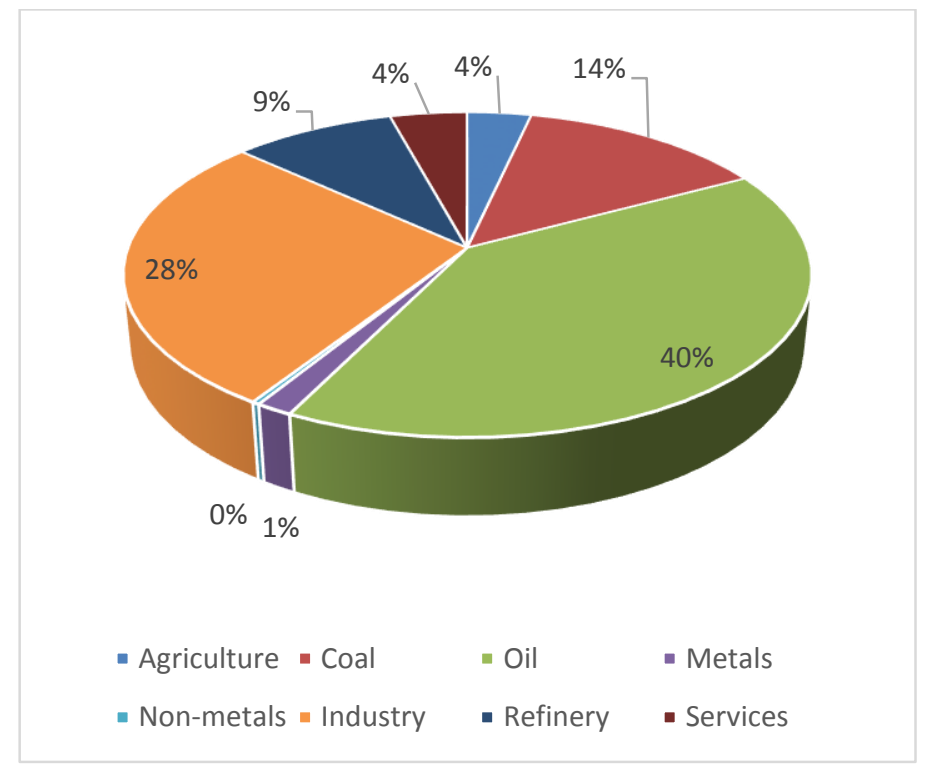

Source: CGE model simulations

Figure 7. Commodities' shares in exports in 2025 (Boom scenario)

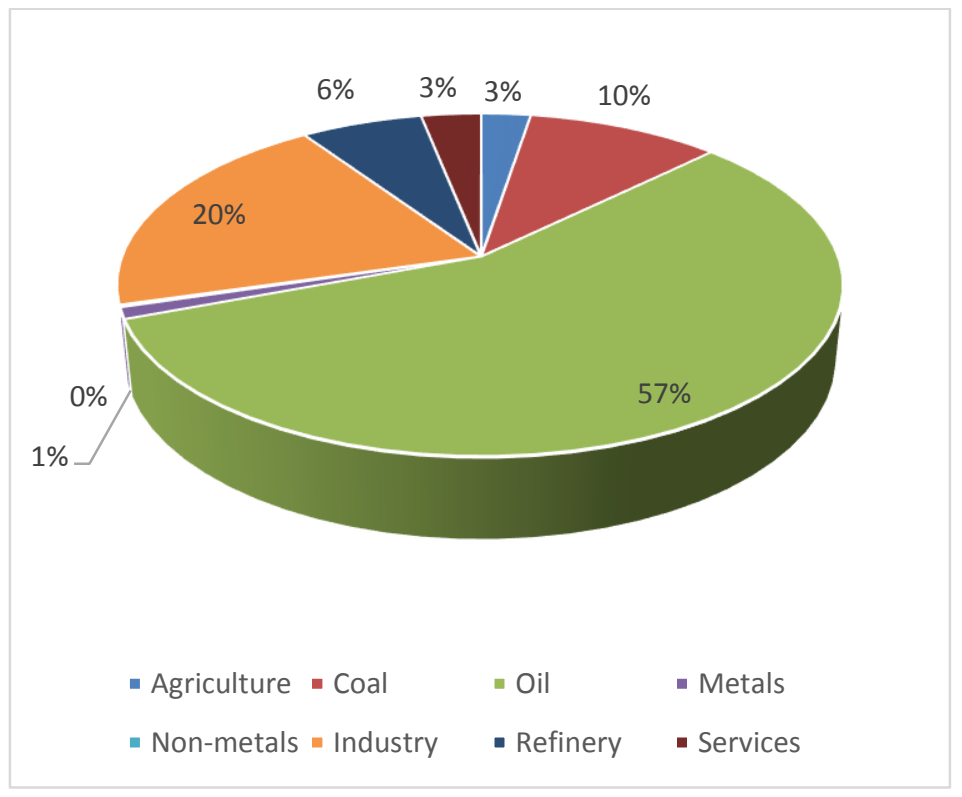

Source: CGE model simulations

This shift is not only due to an expected increase in oil exports, arising from the increase in prices, but also to a decrease in exports of other commodities as compared to their behavior under the baseline scenario. In fact, quantities exported of agricultural goods grow 0.9 percentage points below the average annual compound rate they have under the baseline scenario, and the same is true for the rest of commodities: coal is 0.7 percentage points under, metals 1.1, non-metals 1.1, industrial goods 1 , refinery products 1.4, and 
services 0.8. In contrast, quantities exported of oil grow 2.1 percentage points above their average annual compound rate under the baseline.

This behavior conforms to what could be expected of Dutch Disease effects. The real exchange rate appreciates $13.7 \%$ along the 15 -year span of the simulations for the external balance to hold, as the prices of exportables are linked to international prices and cannot adjust in the face of decreased international competitiveness (for sectors other than oil and, partially, coal) and stronger domestic demand. As the Dutch Disease rationale goes, nontradable sectors have their prices free from international prices to adjust, and with the higher demand that increased income in the economy generates, their prices go up pushing the real exchange rate to appreciate.

In our case, there are two main features of the modeling that may introduce differences with respect to the standard Dutch Disease rationale. First, activities may export more than one commodity and, second, non-tradeable commodities are produced by the informal sectors but, from the demand side, they always are imperfect substitutes with commodities produced by the formal sectors, that are always tradeable.

With respect to the first feature, from an activities point of view, in the cases of agriculture, coal, metals, non-metals, oil, and refinery, their exports only comprise one commodity and therefore changes in commodities' exports "directly" translate into changes in activity levels (through the relevant mechanisms). In the cases of industry and services, exports are composed by more than one commodity (the industry sector exports non-metals, industry products, and services, while the services sector exports industry products and services), so in determining the way changes in exports affect them their basket of exportables must be taken into account. Quantities exported of all the goods exported by the industry and services sectors, increase less under the boom scenario that under the baseline and so does their export value. The value of exports by the industry sector grows 8 percentage points less under the boom scenario than under the baseline, while that by the services sector grows 6 percentage points less. Therefore, the composition of the export basket does not introduce any characteristic of consideration in terms of the standard expected results from the Dutch Disease rationale and our model.

Prior to give consideration to the second feature, it is convenient to examine the behavior of imports and its relationship with demand for domestic products. As a summary measure of the evolution of quantities imported we can examine the differences between the annual average compound growth rate of imports under the boom and baseline scenarios. The relevant figures are presented in table 3. From there, it can be appreciated that imports of all commodities grow faster under the boom scenario than under the baseline (from 1.7 percentage points in the cases of agriculture, coal, metals, and non-metals, to 2.6 percentage points in the case of services). This is a big difference, yielding an increase in imported volumes between the boom scenario and the baseline that amount to $28 \%$ in average, as reported in column three of the table (the increase from the base year reaches $57 \%$ in average).

Import penetration increases in most cases, as demand for domestically produced commodities decreases in relative terms. As shown in the second column of table 3, their annual average compound growth rate decreases with respect to the baseline in $0.2 \%$ in 
average, with the exception of oil, services, and non-metals whose rates increase $0.3 \%, 0.4 \%$, and $0.1 \%$. Given the level of demand for this products at the base year, the increase in volumes demanded are lower under the boom scenario than under the baseline by 2.5 percentage points in average (with respect to the base year, demand for domestically produced goods increases $23 \%$ in average -34 percentage points less than the increase shown for imports). Lastly, total domestic absorption (demand for both domestically produced and imported commodities) increases more under the boom scenario than under the baseline in most cases, while decreases for coal, metals, and public administration services, as shown in the last column of table 3.. For oil, demand for domestically produced goods increases faster under the boom scenario than under the baseline, while there are no imports so the increase in absorption is tantamount to increased production. In the case of services, both imports and demand for domestic services increase faster under the boom scenario and the contribution of imports to total absorption growth is larger under the boom scenario.

Table 3. Differences in annual average growth rates and percentage differences in 2025 for quantities imported and demanded under the boom and baseline scenarios

\begin{tabular}{|l|c|c|c|c|c|}
\hline & \multicolumn{2}{|c|}{ Growth rates } & \multicolumn{3}{c|}{ Levels } \\
\hline & Imports & Domestic & Imports & Domestic & Absorption \\
\hline Agriculture & $1.7 \%$ & $-0.1 \%$ & $25.4 \%$ & $-1.4 \%$ & $1.2 \%$ \\
\hline Coal & $1.7 \%$ & $-0.3 \%$ & $25.8 \%$ & $-4.4 \%$ & $-4.2 \%$ \\
\hline Oil & & $0.3 \%$ & & $4.2 \%$ & $4.2 \%$ \\
\hline Metals & $1.7 \%$ & $-0.2 \%$ & $27.1 \%$ & $-3.2 \%$ & $-2.9 \%$ \\
\hline Non-metals & $1.7 \%$ & $0.1 \%$ & $26.1 \%$ & $1.3 \%$ & $3.7 \%$ \\
\hline Industry & $1.5 \%$ & $-0.1 \%$ & $22.2 \%$ & $-1.3 \%$ & $6.8 \%$ \\
\hline Refinery & $1.8 \%$ & $-0.3 \%$ & $28.6 \%$ & $-4.6 \%$ & $5.3 \%$ \\
\hline Services & $2.6 \%$ & $0.4 \%$ & $43.4 \%$ & $6.1 \%$ & $6.8 \%$ \\
\hline Pub. Adm. & & $0.0 \%$ & & $-0.4 \%$ & $-0.4 \%$ \\
\hline
\end{tabular}

Source: CGE model simulations

How these changes translate at the activity level depends upon the commodity composition of production by sector and the way commodities are destined to the international or the domestic market, in the case of the formal sectors, while for the informal sectors there is a one to one relationship between activity levels and domestic demand. Table 4 shows the behavior of total production by sector (in quantity), in terms of the annual average compound growth rates under the baseline and boom scenarios, as was well as the difference between them. As shown above, demand for domestic commodities increases less under the boom scenario for all commodities but oil, non-metals, and services and this should impinge upon lower increases in total production for informal sectors whose production concentrates in the rest of commodities. The figures in table 4 confirm this, with the exception of informal industry whose output increases slightly more than under the baseline. On the other hand, the informal non-metals and informal services sectors show increases above those under the baseline (coherently with the larger increase in demand for non-metals and services). 
Table 4. Annual average compound growth rates for total quantity produced at the sector level

\begin{tabular}{|l|c|c|c|}
\hline \multicolumn{1}{|c|}{ Sector } & Baseline & Boom & Difference \\
\hline Agriculture formal & $1.4 \%$ & $1.4 \%$ & $0.01 \%$ \\
\hline Agriculture informal & $1.3 \%$ & $1.0 \%$ & $-0.25 \%$ \\
\hline Coal formal & $3.9 \%$ & $3.3 \%$ & $-0.60 \%$ \\
\hline Coal informal & $2.1 \%$ & $1.8 \%$ & $-0.32 \%$ \\
\hline Oil formal & $2.4 \%$ & $4.0 \%$ & $1.64 \%$ \\
\hline Metals formal & $1.3 \%$ & $0.8 \%$ & $-0.55 \%$ \\
\hline Metals informal & $1.3 \%$ & $0.9 \%$ & $-0.34 \%$ \\
\hline Non-metals formal & $1.4 \%$ & $1.1 \%$ & $-0.31 \%$ \\
\hline Non-metals informal & $1.5 \%$ & $1.7 \%$ & $0.26 \%$ \\
\hline Industry formal & $1.4 \%$ & $1.1 \%$ & $-0.25 \%$ \\
\hline Industry informal & $1.0 \%$ & $1.0 \%$ & $0.02 \%$ \\
\hline Refinery formal & $1.6 \%$ & $0.9 \%$ & $-0.69 \%$ \\
\hline Services formal & $1.5 \%$ & $2.1 \%$ & $0.60 \%$ \\
\hline Services informal & $1.0 \%$ & $1.1 \%$ & $0.06 \%$ \\
\hline Public Administration formal & $1.3 \%$ & $1.3 \%$ & $-0.03 \%$ \\
\hline
\end{tabular}

Source: CGE model simulations

With respect to formal sectors, the behavior of total production is nuanced by the interaction between the possibility of diverting production from exports to the domestic market (and vice versa) and production of the same commodities by other formal sectors that is only targeted to the domestic market. With the exception of the oil sector, all formal sectors increase the share of each commodity that they deliver to the domestic market, to the detriment of the export market (since exports of all commodities but oil relatively decrease). As informal sectors and formal sectors delivering a particular product only to the domestic market have no possibility of reducing production by lowering exports, they must accommodate by reducing deliveries to the domestic market. This opens up a space for formal sectors that export and sell to the domestic market to reduce by less the amount of commodity the deliver to the domestic market (this is, for instance, the case of formal agriculture).

In other cases, the scarcity of other sectors delivering the same good to the domestic market leads to a relative decline in deliveries to this market across the board (an example of this is the formal and informal metals sectors). In the cases where demand for the commodity rises relative to the baseline (non-metals and services) the size of the increase determines whether all sectors delivering the good to the domestic market can grow above their baseline levels. While for non-metals the increase is relatively lower than for services, the formal non-metals sector relatively decreases both exports and trades for the domestic market, while the informal non-metals sector relatively increases. In the case of services, the increase in demand for the commodity suffices for generating relative increases for the formal and informal services sectors. For this sector, the one besides oil that increases total production the most above the baseline level, the driver for its growth stems from the inputoutput relationships that maintain, especially for self-intermediate consumption that tends to amplify the feedback effects. 
A point is that is important to make here is that in this dynamics there is no role for potential substitution between commodities commonly produced by the formal an informal sectors, as there is nothing in the shock to international prices that affects relative prices between these sectors. Price differences between them (say agricultural products originated in the formal sector and originated in the informal sector) arise only from indirect taxes applied to the product generated by the formal sector. Therefore, from the standpoint of the composite good that is demanded in the economy, the shares corresponding to formal and informal supply remain constant.

Having discussed changes in the sectorial composition of the economy and changes in import penetration as they are transmitted to the sectorial level, we can now turn to examine the ensuing changes in labor demand. Table 5 shows the annual average compound growth rates for informal employment at the sector level. From there it can be appreciated that unskilled workers employment grow less under the boom scenario for agriculture, coal, and metals, and does it more for non-metals, industry, and services, inducing a slight change in the sectorial composition of this type of employment. As for skilled workers, employment increases faster under the boom scenario only for the nonmetals sector, an activity with a low share in this type of employment so there are scant changes in the composition of sectorial employment in this case.

Table 5. Annual average compound growth rates for informal employment at the sectorial level (boom scenario)

\begin{tabular}{|l|r|r|r|r|}
\hline \multirow{2}{*}{ Sector } & \multicolumn{2}{|c|}{ Unskilled informal } & \multicolumn{2}{c|}{ Skilled informal } \\
\cline { 2 - 5 } & Baseline & Boom & Baseline & Boom \\
\hline Agriculture informal & $1.28 \%$ & $1.02 \%$ & $1.13 \%$ & $0.75 \%$ \\
\hline Coal informal & $2.20 \%$ & $1.84 \%$ & $2.05 \%$ & $1.57 \%$ \\
\hline Metals informal & $1.27 \%$ & $0.82 \%$ & $1.12 \%$ & $0.55 \%$ \\
\hline Non-metals informal & $1.48 \%$ & $1.80 \%$ & $1.33 \%$ & $1.52 \%$ \\
\hline Industry informal & $0.98 \%$ & $1.05 \%$ & $0.83 \%$ & $0.78 \%$ \\
\hline Services informal & $0.97 \%$ & $1.06 \%$ & $0.82 \%$ & $0.78 \%$ \\
\hline
\end{tabular}

Source: CGE model simulations

Table 6 shows the average growth rates at the sector level for formal employment. In the case of unskilled workers, growth rates are higher under the boom scenario for agriculture, oil, services and public administration. In spite of the high growth rate in the oil sector, its share in this type of employment only increases from $1.2 \%$ under the baseline to $1.7 \%$ under the boom scenario. Even though this type of employment in agriculture and public administration grow more under the boom scenario, these sectors lose share as compared to the baseline. With respect to skilled workers, growth rates are higher under the boom scenario for oil and services, increasing their share in this type of employment. Under the boom scenario, the annual growth rates for unskilled and skilled workers grow 0.6 and 0.4 percentage points more.

Labor demand changes arising from the sectorial level generate the following picture in terms of labor market behavior. Demand for informal unskilled workers grow less under the boom scenario leading to a relative drop in demand of around $0.4 \%$ with respect to the baseline. A similar result is attained for informal skilled workers, as demand for them grows 
less under the boom scenario yielding a decline in demand for this type of labor of $0.8 \%$ relative to the baseline. In contrast, demand for formal workers is stronger under the boom scenario, in particular in the case of unskilled workers. For this type of workers, a higher demand growth rate leads to an increase in demand under the boom scenario equivalent to $9.7 \%$ with respect to the baseline. In the case of skilled workers, demand is $6.2 \%$ higher under the boom scenario.

Table 6. Annual average compound growth rates for formal employment at the sectorial level (boom scenario)

\begin{tabular}{|l|r|r|r|r|}
\hline \multirow{2}{*}{ Sector } & \multicolumn{2}{|c|}{ Unskilled formal } & \multicolumn{2}{c|}{ Skilled formal } \\
\cline { 2 - 5 } & Baseline & Boom & Baseline & \multicolumn{1}{c|}{ Boom } \\
\hline Agriculture formal & $1.42 \%$ & $1.51 \%$ & $1.42 \%$ & $1.31 \%$ \\
\hline Coal formal & $1.38 \%$ & $-0.52 \%$ & $1.38 \%$ & $-0.72 \%$ \\
\hline Oil formal & $1.27 \%$ & $4.73 \%$ & $1.27 \%$ & $4.52 \%$ \\
\hline Metals formal & $1.32 \%$ & $0.35 \%$ & $1.32 \%$ & $0.16 \%$ \\
\hline Non-metals formal & $1.46 \%$ & $1.18 \%$ & $1.46 \%$ & $0.99 \%$ \\
\hline Industry formal & $1.38 \%$ & $1.14 \%$ & $1.38 \%$ & $0.94 \%$ \\
\hline Refinery formal & $1.78 \%$ & $0.83 \%$ & $1.78 \%$ & $0.64 \%$ \\
\hline Services formal & $1.53 \%$ & $2.42 \%$ & $1.53 \%$ & $2.22 \%$ \\
\hline Public administration & $1.31 \%$ & $1.47 \%$ & $1.31 \%$ & $1.27 \%$ \\
\hline
\end{tabular}

Source: CGE model simulations

Jointly, demand for informal workers is $0.6 \%$ lower under the boom scenario, while demand for formal workers is $6.7 \%$ higher. On the other hand, demand for unskilled workers in general is $2.3 \%$ higher under the boom scenario, but the increase is entirely due to demand for formal workers (as that for informal workers declines). Demand for skilled workers increases too under the boom scenario with respect to the baseline by $4.3 \%$, with the increase, again, entirely due to demand for formal workers. Therefore, the oil price increase favors formal over informal employment and within the latter, skilled over unskilled labor.

The relative decline in informal employment is sustained by lower "migration" of formal workers to the informal segment of the market, which, in turn, is possible due to lower unemployment rates in the formal segment. In particular, the unemployment rate lowers the most for skilled workers.

Results for the increase in the capital stock at the sectorial level are analogous to those found in the case of labor. The annual average compound growth rate for capital is higher under the boom scenario for formal agriculture, oil, informal non-metals, informal industry, and formal and informal services. Therefore, there is, in general, a shift of resources from the rest of the economy to this set of sectors and, especially, to the oil sector. ${ }^{7}$ The capital stock of the economy under the boom scenario situates $6.6 \%$ above the baseline level.

\footnotetext{
${ }^{7}$ We qualify this as a general result due to the fact that increases in labor demand are not homogeneous among these sectors. In the case of formal agriculture the shift is confined to unskilled labor and the same is true in the cases of informal industry and informal services.
} 
In a "standard" Dutch Disease setting, commodities produced by the informal sector would be treated as purely non-tradable and therefore the spending effect would increase their prices, further pushing the real exchange rate up. In our modeling, this type of commodities do not directly compete with imports, but their prices are "disciplined" by international prices as they are imperfect substitutes with the composite imports-"formal" commodities. As a consequence, even though there is nothing in the shock we model that changes relative prices between commodities produced by formal and informal activities (as mentioned above), their shares in total absorption change due to foreign competition.

Under the boom scenario, the ratio between international prices and the prices of commodities produced by formal activities decreases with respect to the baseline, so imports increase their share in domestic absorption. On the other hand, the ratio between the price of the composite imports-"formal" commodities and the price of commodities produced by informal activities also declines under the boom scenario, but it does so to a lesser extent. Therefore, the composite commodity increases its share in domestic absorption at the expense of "informal" commodities at a lower degree than that experienced by "formal" commodities. As a result, we have a tendency for production of "formal" commodities to shrink more than that of "informal" commodities.

In general, demand for domestically produced commodities decreases as a whole under the boom scenario for all commodities but oil, non-metals, and services (the first due to international prices and the others due to input-output linkages). Within the composite imports-"formal" commodity, the share of "formal" commodities decreases in all cases with respect to the baseline and within the composite imports-"formal" commodity-"informal" commodity the share of "informal" commodities also decreases, but it does so to a lesser extent. Although these variations are quite heterogeneous in levels across commodities, just to give an idea of the difference in shares within the two nests, it can be said that in average the decrease in shares for "formal" commodities is around $2.2 \%$, while among "informal" commodities it is around $0.3 \%$. Therefore, the standard spending effect is ameliorated in this case, as the prices of "informal" commodities indirectly depend upon international prices.

As mentioned, part of the policy response by the Colombian government in facing potential Dutch Disease effects arising from increased oil exports is the establishment of a saving and stabilization fund (FAE for its acronym in Spanish language), targeted to withhold up to $30 \%$ of royalties revenue. These resources are meant to be invested abroad by the Central Bank and kept outside of the economy, as a classic sterilization scheme, unless needed to be used as countercyclical spending, should oil prices or exported volumes decline below an expected threshold.

Our third scenario, identified as FAE, simulates the effects of this measure, assuming that $30 \%$ of royalties revenue is saved throughout the entire period. The expected effect of this measure is to dump to some degree the spending effect arising from the oil boom, in this case particularly through decreasing demand for investment goods. The results from the simulation confirm this expectation. Real GDP at basic prices increases less than under the boom scenario, as illustrated in figure 8, while cumulated reserves in the FAE grow to reach around $8 \%$ of real GDP in 2025. This lower growth is due to the minor level of capital accumulation achieved by the sterilization scheme. 
Figure 8. Real GDP at basic prices under the baseline, boom, and FAE scenarios

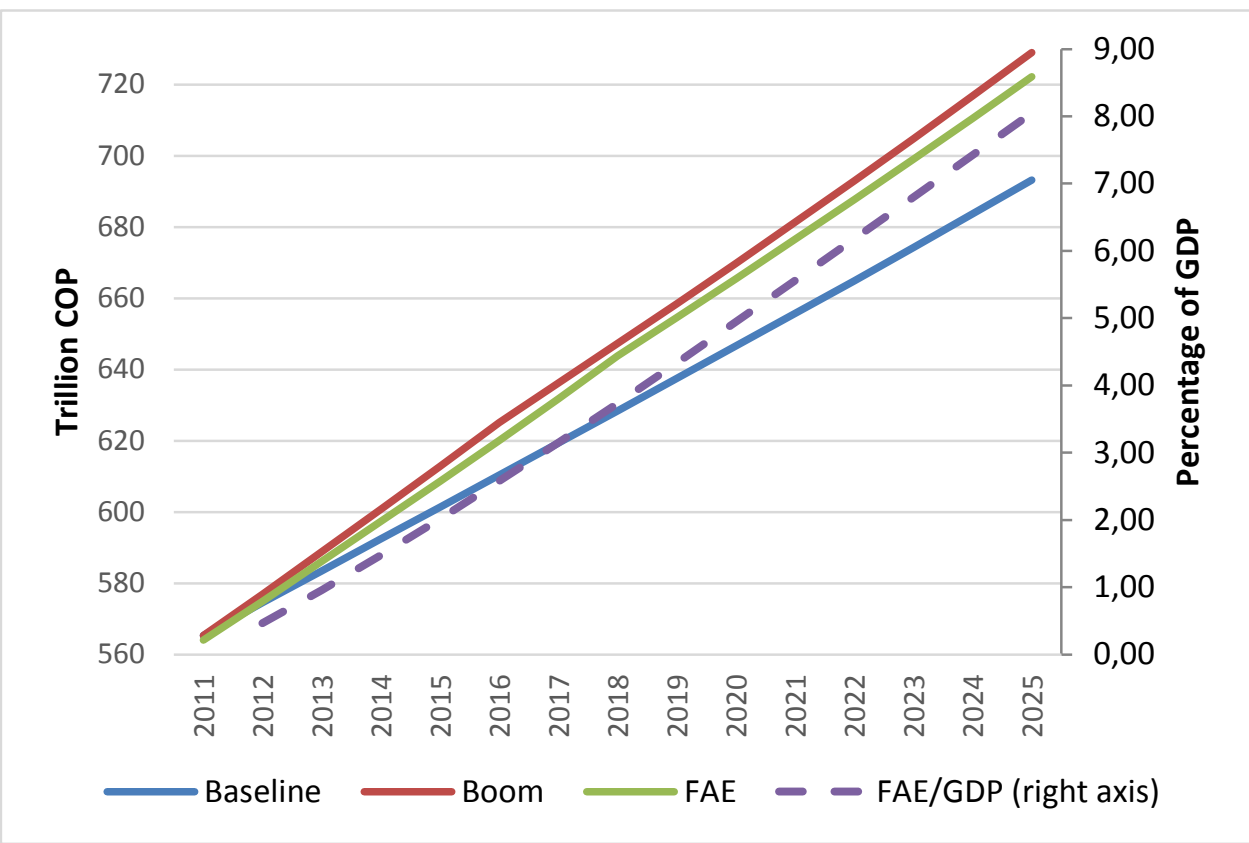

Source: CGE model simulations

While all changes registered in the economy under this scenario essentially mimic those discussed previously in their direction but differ in level, we concentrate the discussion in the changes in variables related to the spending and the resource shift effects. The central tenet of the sterilization scheme is to curb spending to some degree. This is reflected in the behavior of total domestic demand, demand for imports and demand for investment. We first discuss the behavior of total domestic demand and demand for imports and leave demand for investment for later reference.

Demand for domestically produced goods falls for all commodities except oil, non-metals, and services and it does so to a greater extent than under the boom scenario, with differences ranging in between 0.6 and 1.1 percentage points. On the other hand, for the commodities whose demand increases, the increase is lower under the FAE scenario than under the boom scenario, with differences ranging between 0.8 and 1.4 percentage points.

On the side of demand for imports we have a similar situation. While imports partly substitute for domestically produced commodities, the degree to which they succeed is lower under the FAE scenario in the face of lower disposable income in the economy. Demand for imports decreases in all cases with respect to the boom scenario, by 2.9 percentage points in the cases of agriculture and coal, by 2.5 percentage points for metals, 3.1 percentage points for non-metals, 2.7 for industry, 1.7 for refinery, and 4.5 for services.

With respect to resource shift effects, tables 7 and 8 show labor demand changes at the activity level induced under the FAE scenario. From table 7 can be appreciated that all changes in labor demand for informal workers follow the same trend than under the boom scenario but their sizes differ. That is, in the cases in which labor demand decreases under the boom scenario with respect to the baseline, it decreases too under the FAE scenario but at a rate to some extent higher, leading to greater differences with respect to the baseline. 
On the contrary, in the cases in which labor demand increases under the boom scenario with respect to the baseline, under the FAE scenario the increase is somewhat damped, getting closer to the baseline. The exception to the two observations is demand by informal services for both unskilled and skilled workers, which increases more under the FAE scenario. Interestingly, as follows from the figures in table 8, most labor demand outcomes for formal activities yield higher increases under the FAE scenario than under the boom scenario. The exceptions to this are demand for both unskilled and skilled workers by formal agriculture, and demand for informal workers by the metals, industry and public administration sectors.

Table 7. Annual average compound growth rates for informal employment at the sectorial level (FAE scenario)

\begin{tabular}{|l|r|r|r|r|}
\hline \multirow{2}{*}{ Sector } & \multicolumn{2}{|c|}{ Unskilled informal } & \multicolumn{2}{c|}{ Skilled informal } \\
\cline { 2 - 5 } & Baseline & FAE & Baseline & FAE \\
\hline Agriculture informal & $1.28 \%$ & $1.02 \%$ & $1.13 \%$ & $0.74 \%$ \\
\hline Coal informal & $2.20 \%$ & $1.83 \%$ & $2.05 \%$ & $1.55 \%$ \\
\hline Metals informal & $1.27 \%$ & $0.80 \%$ & $1.12 \%$ & $0.53 \%$ \\
\hline Non-metals informal & $1.48 \%$ & $1.70 \%$ & $1.33 \%$ & $1.42 \%$ \\
\hline Industry informal & $0.98 \%$ & $0.97 \%$ & $0.83 \%$ & $0.69 \%$ \\
\hline Services informal & $0.97 \%$ & $1.07 \%$ & $0.82 \%$ & $0.79 \%$ \\
\hline
\end{tabular}

Source: CGE model simulations

Table 8. Annual average compound growth rates for formal employment at the sectorial level (FAE scenario)

\begin{tabular}{|l|r|r|r|r|}
\hline \multirow{2}{*}{ Sector } & \multicolumn{2}{|c|}{ Unskilled formal } & \multicolumn{2}{c|}{ Skilled formal } \\
\cline { 2 - 5 } & Baseline & FAE & Baseline & FAE \\
\hline Agriculture formal & $1.42 \%$ & $1.42 \%$ & $1.42 \%$ & $1.29 \%$ \\
\hline Coal formal & $1.38 \%$ & $-0.51 \%$ & $1.38 \%$ & $-0.64 \%$ \\
\hline Oil formal & $1.27 \%$ & $4.74 \%$ & $1.27 \%$ & $4.60 \%$ \\
\hline Metals formal & $1.32 \%$ & $0.32 \%$ & $1.32 \%$ & $0.19 \%$ \\
\hline Non-metals formal & $1.46 \%$ & $1.20 \%$ & $1.46 \%$ & $1.07 \%$ \\
\hline Industry formal & $1.38 \%$ & $1.13 \%$ & $1.38 \%$ & $0.99 \%$ \\
\hline Refinery formal & $1.78 \%$ & $0.86 \%$ & $1.78 \%$ & $0.73 \%$ \\
\hline Services formal & $1.53 \%$ & $2.42 \%$ & $1.53 \%$ & $2.29 \%$ \\
\hline Public administration & $1.31 \%$ & $1.44 \%$ & $1.31 \%$ & $1.31 \%$ \\
\hline
\end{tabular}

Source: CGE model simulations

At a more structural level, demand for unskilled and skilled informal workers decreases moderately less under the FAE than under the boom scenario for both types, while demand for unskilled and skilled formal workers increases less under the FAE, again for both types. As a consequence, under the FAE scenario, demand for informal workers decreases less than under the boom scenario and demand for formal workers increases less. From the viewpoint of qualification, demand for unskilled workers increases less under the FAE scenario and the increase is entirely due to demand for formal workers, while demand for skilled workers increases meagerly more under the FAE scenario, but this larger increase is basically due to a lower decline in demand for informal workers. 
On the side of capital, demand increases with respect to the baseline only for oil and formal services, while it decreases for the rest of activities. However, these increases are of a lower magnitude than the ones corresponding to the boom scenario by 0.8 and 3.2 percentage points, respectively. Therefore, although to a lesser extent, there is also a clear resource shift in favor of oil and services. In a more general setting, the capital stock of the economy is 4.5\% higher under the FAE scenario than under the baseline, but is also 1.9 percentage points below the one attained under the boom scenario. The difference is due to lower investment originated in the operation of the sterilization scheme, which leads to lower demand for investment purposes for agriculture, industry, and services, with respect to the boom scenario, in the order of $3.2 \%, 3.5 \%$, and $3.2 \%$, correspondingly. These lower demand levels feed also back, through input-output linkages, and show up in changes in factor demand, as discussed previously.

\section{Conclusions and policy implications}

We have examined the likely effects of an oil price boom, sustained until 2025 and behaving according to price projections made in 2013, before the 2015 price plunge in international markets. According to our estimations, the Colombian economy would have grown in real terms at an annual average rate of $1.8 \%$ instead of at $1.5 \%$, as projected under the baseline.

This stronger growth would have been led by oil exports, which in 2025 would reach $57 \%$ of total export value as compared to $40 \%$ under the baseline. The higher inflow of foreign exchange, almost $30 \%$ above that under the baseline, would generate a $13.7 \%$ appreciation of the real exchange rate, with the concomitant disincentive for exports other than oil.

The higher income accruing to the economy, pushes domestic absorption up which is basically met by increased imports as domestic production shifting from exports to the domestic market is incapable of keeping the pace of increased demand. Import penetration at the product level increases in all cases, varying from 0.2 to 6.6 percentage points, according to the specific product.

The mix of lower exports and lower demand for domestically produced goods, leads to lower production levels for the majority of products. The exceptions to this are oil, nonmetallic minerals, and services, which in spite of facing higher imports show increased domestic production. The transmission of these changes to the sector level is mediated by the fact that activities may produce more than one commodity and, furthermore, may be formal or informal.

As a result, at the sectorial level, while in terms of gross product at current prices all activities but formal coal (which suffers a negative international price shock) grow faster than under the baseline, most sectors grow less in total quantity produced. While formal agriculture, oil, informal non-metals, informal industry, and formal and informal services grow more than under the baseline, the remaining nine sectors shrink.

These changes determine the extent to which factor demand behaves. As could be expected, labor demand in the cases of activities that expand total production faster under the oil price boom tends to grow more while for the rest of sectors it does the opposite. 
However, with the exception of the oil sector, demand for skilled workers for these sectors increases at a slighter lower pace than under the baseline. A similar behavior is observed with respect to capital use. The sectors whose total physical production increases more rapidly under the oil boom scenario show higher relative increases in capital use.

Notwithstanding this resource shift effect, it is possible to further qualify the effects of the oil boom in terms of demand for labor. In the aggregate, under the oil boom scenario demand for skilled workers increases more than does demand for unskilled workers (even though both increase more than under the baseline), while demand for formal workers increases more and for informal workers increases less. Therefore, the oil boom shifts incentives in the labor market in favor of skilled formal workers.

The sectorial composition of the economy, in terms of its gross value, shifts in favor of the oil and services sectors as compared to the baseline and the share of oil and mining related governmental income in total governmental income increases form $11.9 \%$ under the baseline to $16 \%$ under the oil boom scenario.

It is important to notice that, although the informal activities do not export nor do they directly compete with imports, there is nothing in the shock that affects relative prices for the like products produced in the formal and informal sectors. Therefore, the proportion with which the economy produces goods in the formal and informal sectors remains unaltered. As agents in the economy demand a composite good that mixes imports with goods generated in the formal sectors in the first place and then with goods produced in the informal sectors, prices for the latter are indirectly disciplined by international prices, ameliorating the usual Dutch Disease effect that leads to an increase in the prices of nontradables (or a decrease, depending on their degree of substitutability with formal products).

In sum, a sustained oil price boom would lead to both resource shift and spending effects in the economy with the consequent relative erosion of its export base and some degree of "deindustrialization". The operation by the government of the FAE, tends to lower these effects but it does so to a relatively limited degree. A more successful intervention should probably comprise a more aggressive saving strategy and increased spending in the provision of public goods that may impinge upon non boom sectors' productivity (like roads, applied research, education, and infrastructure in general).

Along with the $F A E$, the government created two other funds, a regional compensation fund and a regional development fund (FCR and FDR, respectively, for their acronyms in Spanish language). The first is aimed at channeling social spending in local projects, basically a way to redistribute non directly productive spending across regions, and the second is targeted to develop regional productive projects. The latter was designed to start operations in 2014, a moment at which the set of projects it could carry out would begin to be defined. As further work, we will extend the model to appraise the likely impact that the implementation of the FDR may have for improving governmental intervention for facing Dutch Disease. 


\section{References}

Collier, P. and B. Goderis. (2007), Commodity Prices, Growth and the Natural Resources Curse: Reconciling a Conundrum, The Centre for the Study of African Economies Working Paper Series, Working Paper 276. Oxford.

Corden, W.M. and P. Neary (1982), "Booming sector and deindustrialization in a small open economy", Economic Journal, 92: 835-848.

Edwards, S. (1986), "Coffee, money and inflation in Colombia", en V, Thomas (ed.) Linking Macroeconomic and Agricultural Policies for Adjustment with growth: the Colombian Experience, Johns Hopkins University Press, Baltimore, MD.

Decaluwe, B., A. Lemelin, H. Maisonave and V. Robichaud (2012), The PEP Standard Computable General Equilibrium Model. Single Country, Recursive Dynamic Version, PEP-1t, version 2.0, Partnership for Economic Policy (PEP) Research Network, Québec, mimeo, May.

Harris, J and M. Todaro (1970) Migration, unemployment and development: A two sector analysis, American Economic Review, 60, 126-142.

Lederman, D. and W.F. Maloney (2008) "In Search of the Missing Resource Curse." World Bank Policy Research Working Paper, WPS 4766. Washington, DC.

Magud, N. and S. Sosa (2010), When and Why Worry About Real Exchange Rate Appreciation? The Missing Link Between Dutch Disease and Growth, IMF Working Paper, WP/10/271, December.

Ministry of Finance and Public Credit (2011), ¿̇Por qué es necesaria la creación de un Sistema General de Regalías? J.C. Echeverry, G. Masmela, and A: García, Notas Fiscales, No. 2, January.

Olivera, Mauricio, Sandra Cortes, and Tatiana Aguilar (2013), Ingresos Fiscales por Explotación de Recursos Naturales en Colombia, Resumen de Políticas No. IDB-PB-196, Banco Interamericano de Desarrollo.

Rojas, N. and D. Forero (2011), Bonanza petrolera: ¿Cómo aprovecharla? Entrega Final, Concurso Germán Botero de los Ríos 2010.

Sachs, J.D. and A.M. Warner (2001), "The Curse of Natural Resources", European Economic Review, 45(4-6):827-38, May.

Sala-i-Martin, X and A. Subramanian (2003), "Addressing the Natural Resource Curse: An lllustration from Nigeria", IMF Working Paper 03/139, International Monetary Fund, Washington, DC, July.

Spatafora N. and A. Warner (1995), Macroeconomic Effects of Terms-of-Trade Shocks: the Case of Oil Exporting Countries, Policy Research Working Paper, 1410, the World Bank. 
Treviño, J.P. (2011), Oil Price Boom and Real Exchange Rate Appreciation: Is There Dutch Disease in the CEMAC?, IMF Working Paper, WP/1 1/268, November.

\section{Annex}

Implementation of the composite commodity

$$
\begin{aligned}
& Q F_{i, t}=B_{-} M_{i} *\left[\beta_{-} M_{i} * I M_{i, t}{ }^{-\rho_{-} M_{i}}+\left(1-\beta_{-} M_{i}\right) * D D F_{i, t}{ }^{-\rho_{-} M_{i}}\right]^{\left(-1 / \rho_{-} M_{i}\right)} \\
& I M_{i, t}=\left[\frac{\beta_{-} M_{i}}{\left(1-\beta_{-} M_{i}\right)} * \frac{P D F_{i, t}}{P M_{i, t}}\right]^{\sigma_{-} M_{i}} * D D F_{i, t} \\
& Q_{i, t}=B_{-} Q_{i} *\left[\beta_{-} Q_{i} * Q F_{i, t}{ }^{-\rho_{-} Q_{i}}+\left(1-\beta_{-} Q_{i}\right) * D D I_{i, t}{ }^{\left.-\rho_{-} Q_{i}\right]}\right]^{\left(-1 / \rho_{-} Q_{i}\right)} \\
& Q F_{i, t}=\left[\frac{\beta_{-} Q_{i}}{\left(1-\beta_{-} Q_{i}\right)} * \frac{P D I_{i, t}}{P Q F_{i, t}}\right]^{\sigma_{-} M_{i}} * D D I_{i, t} \\
& \left.D D_{i, t}=B_{-} D D_{i} *\left[\beta_{-} D D_{i} * D D F_{i, t}{ }^{-\rho_{-} D D_{i}}+\left(1-\beta_{-} D D_{i}\right) * D D I_{i, t}{ }^{-\rho_{-} D D_{i}}\right]^{\left(-1 / \rho_{-} D D_{i}\right.}\right) \\
& D D F_{i, t}=\left[\frac{\beta_{-} D D_{i}}{\left(1-\beta_{-} D D_{i}\right)} * \frac{P D I_{i, t}}{P D F_{i, t}}\right]^{\sigma_{-} D D_{i}} * D D I_{i, t} \\
& P D F_{i, t}=\left(1+t t i c_{i, t}\right) *\left[P L_{i, t}+\sum_{i} P C_{i, t} * t m r g_{i j, i}\right] \\
& P D I_{i, t}=\left[P L_{i, t}+\sum_{i} P C_{i, t} * \operatorname{tmr} g_{i j, i}\right] \\
& P C_{i, t} * Q_{i, t}=\left(P Q F_{i, t} * Q F_{i, t}\right)+\left(P D I_{i, t} * D D I_{i, t}\right) \\
& P Q F_{i, t} * Q F_{i, t}=\left(P D F_{i, t} * D D F_{i, t}\right)+\left(P M_{i, t} * I M_{i, t}\right)
\end{aligned}
$$

Where:

$Q F_{i, t}:$ Quantity demanded of "formal" composite commodity $i$

$I M_{i, t}:$ Quantity of product i imported

$D D F_{i, t}$ : Demand for domestic formally produced commodity $i$

$Q_{i, t}:$ Quantity demanded of composite commodity $i$

$D D_{i, t}$ : Domestic demand for commodity i produced locally

$P D F_{i, t}$ : Price of "formal" composite commodity $i$

$P M_{i, t}$ : Price of imported product $i$ (including all taxes and tariffs)

$P D I_{i, t}$ : Price of "informal" domestic product $i$ sold in the domestic market 
$P Q F_{i, t}$ : Price of "formal" composite commodity $i$

$P L_{i, t}$ : Price of local product $i$ (excluding all taxes on products)

$P C_{i, t}$ : Purchaser price of composite comodity $i$ (including all taxes and margins)

$B_{-} M_{i}:$ Scale parameter (CES - composite "formal" commodity)

$\beta_{-} M_{i}$ : Share parameter (CES - composite "total" commodity)

$\rho_{-} M_{i}$ : Elasticity parameter (CES - "formal" composite commodity)

$\sigma_{-} M_{i}:$ Elasticity (CES - composite "formal" commodity)

$B_{-} Q_{i}:$ Scale parameter CES (composite "total" commodity)

$\beta_{-} Q_{i}$ : Share parameter (CES - composite "total" commodity)

$\rho_{-} Q_{i}:$ Elasticity parameter (CES - "total" composite commodity)

$\sigma_{-} Q_{i}:$ Elasticity (CES - composite "total" commodity)

$B_{-} D D_{i}$ : Scale parameter (CET - "composite domestic formal - informal" commodity

$\beta_{-} D D_{i}:$ Share parameter (CET - "composite domestic formal - informal" commodity)

$\rho_{-} D D_{i}$ : Elasticity parameter (CET - "composite domestic formal - informal" commodity)

$\sigma_{-} D D_{i}:$ Elasticity (CET - "composite domestic formal - informal" commodity)

ttic $_{i, t}$ : Tax rate on commodity $i$

tmrg $_{i j, i}:$ Rate of margin $i$ applied to exported commodity $i$

Implementation of the labor market

$$
\begin{aligned}
& \left(L S_{l f, t}-M I G R_{l f, t}\right) *\left(1-U E R A T_{l f, t}\right)=\sum_{j} L D_{l f, j, t} \\
& \left(L S_{l i, t}+\sum_{l f} M I G R_{l f, t}\right)=\sum_{j} L D_{l i, j, t} \\
& \operatorname{MIGR}_{l f, t}=\zeta_{l f} *\left\{\frac{\sum_{l i} W_{l i, t}}{\left(1-U E R A T_{l f, t}\right) * W_{l f, t}}\right\}^{\psi_{l}} \\
& W R E A L_{l, t}=\frac{W_{l, t}}{\text { PIXCON }_{t}} \\
& W R E A L M I N_{l f, t}=\frac{W O_{l f, t}}{P I X C O N O} \\
& W R E A L_{l f, t} \geq W R E A L M I N_{l f, t} \\
& \min \left(U E R A T_{l f, t}\right)=\text { ueratmin }_{l f}
\end{aligned}
$$

Where:

$L S_{l, t}$ Supply of type l labor

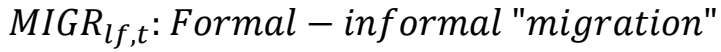

$U_{E R A T}, t:$ Unemployment rate factor $l$

$L D_{l, j, t}$ : Demand for type l labor by industry $j$

$W_{l, t}$ 
$W R E A L_{l, t}:$ Real wage rate factor $l$

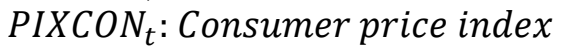

$W R E A L M I N_{l f, t}:$ Minimum real wage rate factor $l$

$W O_{l f, t}:$ Wage rate of type l labor (base year)

PIXCONO: Consumer price index (base year)

ueratmin $_{l f}$ : Minimum unemployment rate factor $l$

Implementation of royalties and oil dividends payments

$$
\begin{aligned}
& Y G R E G_{t}=\sum_{n r}\left[\lambda \_R K_{g v t, n r} * \sum_{j}\left(R_{n r, j, t} * K D_{n r, j, t}\right)\right] \\
& Y G D I P_{t}=\sum_{f} F D I P_{f, t} \\
& Y G D I O_{t}=\omega_{-} D V_{g v t, d i o} * \sum_{f} F D I O_{f, t} \\
& Y R O W D I V_{t}=\omega_{-} D V_{\text {row }, \text { div }} * \sum_{f} F D I V_{f, t} \\
& Y H D I V_{t}=\omega_{-} D V_{h, d i v} * \sum_{f} F D I V_{f, t} \\
& F D I V_{f, t}=\omega_{-} F D_{d i v, f} * Y F K_{f, t} \\
& F D I O_{f, t}=\omega_{-} F D_{d i o, f} * Y F K_{f, t} \\
& F D I P_{f, t}=\omega_{-} F D I P_{f} * \sum_{k a, j o i l} T D I P_{k a, j o i l, t} * K D_{k a, j o i l, t} * R_{k a, j o i l, t} \\
& T D I P_{k a, j o i l, t}=t d i p O_{k a, j o i l}\left[\frac{e_{t} * P W X_{c o i l, t}}{P E_{-} F O B_{c o i l, t}}\right]^{\sigma \_R E G_{j o i l}}
\end{aligned}
$$

Where:

$Y G R E G_{t}$ : Government's income form royalties

$R_{n r, j, t}:$ Rental rate of type $k$ capital in industry $j$

$K D_{n r, j, t}$ : Demand for type $k$ capital by industry $j$

$Y$ YDIP $P_{t}$ : Government's income form oil dividends

$F D I P_{f, t}:$ Firms'payments of oil dividends

YGDIO ${ }_{t}$ : Government's income form non - oil dividends

$F D I O_{f, t}:$ Non - oil governmental firms dividends

YROWDIV ${ }_{t}$ :ROW's income from dividends

FDIV $V_{f, t}:$ Firms $^{\prime}$ payments for dividends 
YHDIV $V_{t}$ Households' income from dividends

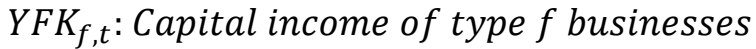

$T D I P_{k a, j o i l, t}:$ Tax rate on oil (endogenous)

$e_{t}:$ Exchange rate (price of foreign currency in local currency)

$P W X_{\text {coil }, t}:$ World price of exported product $i$ (expressed in foreign currency)

$P E_{-} F O B_{\text {coil }, t}: F O B$ price of exported commodity $i$ (in local currency)

$\lambda_{-} R K_{g v t, n r}$ : Share of type $k$ capital income received by agent ag

$\omega_{-} D V_{g v t, d i o}$ : Agents share in income from dividends

$\omega_{-} F D_{\text {div,f }}$ : Dividends share in firms capital income

$\omega_{-} F D I P_{f}:$ Firm's type share in oil dividends

tdip $O_{k a, j o i l}$ : Tax rate on oil (gov't dividends)

$\sigma_{-} R E G_{j o i l}:$ Elasticity of oil dividends to international prices

Implementation of FDI for oil and mining

$$
\begin{gathered}
\text { CAPFLOW }_{t}=S R O W_{t}-\text { FDIMIN }_{t} \\
\text { GFCF }_{t}=I T_{t}-\left(\sum_{i} P C_{i, t} * V S T K_{i, t}\right)+\text { FDIMIN }_{t} \\
I T_{t}=\sum_{h} S H_{h, t}+\sum_{f} S F_{f, t}+S G_{t}+\text { CAPFLOW }_{t} \\
I T_{-} P R I_{t}=I T_{t}-I T_{-} P U B_{t}-\left(\sum_{i} P C_{i, t} * V S T K_{i, t}\right)+F D I M I N_{t} \\
I T_{-} P R I_{t}=P K_{-} P R I_{t} *\left(\sum_{k, b u s} I N D_{k, b u s, t}\right)+F D I M I N_{t} \\
K D_{k, j, t}=K D_{k, j, t-1} *\left(1-\delta_{k, j}\right)+I N D_{k, j, t-1}+f d i s h r_{k, j} * F D I M I N_{t}
\end{gathered}
$$

Where:

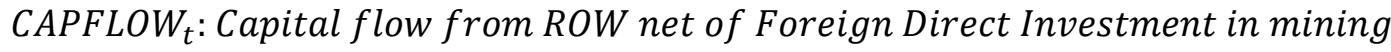
$S R O W_{t}:$ Rest - of - the - world savings

FDIMIN $N_{t}$ :FDI in the oil and mining sectors (in local currency)

$G F C F_{t}$ : Gross fixed capital formation

$I T_{t}:$ Total investment expenditures

$P C_{i, t}:$ Purchaser price of composite comodity $i$ (including all taxes and margins)

$V S T K_{i, t}$ : Inventory change of commodity $i$

$\mathrm{SH}_{h, t}$ : Savings of type $h$ households

$S F_{f, t}$ : Savings of type $f$ businesses

$S G_{t}:$ Government savings

$I T_{-} P R I_{t}:$ Total private investment expenditures

$I T_{-} P U B_{t}$ : Total public investment expenditures

$P K_{-} P R I_{t}$ : Price of new private capital 
IND $D_{k, b u s, t}:$ Volume of new type $k$ capital investment to industry $j$

$\delta_{k, j}$ : Depreciation rate of capital $k$ in industry $j$

fdishr $_{k, j}$ : Share of sector $j$ in capital type $k$ accruing as FDI

Implementation of the FAE

$$
\begin{aligned}
& Y G F A E_{t}=\text { faeintrat } * F A E A C C_{t} \\
& F A E_{t}=\text { faerat }_{t} * Y G R E G_{t} \\
& \left.S R O W_{t}=Y R O W_{t}-\left(\sum_{i} P E_{F O B} i, t\right) E X D_{i, t}\right)-\left(\sum_{a g d} T R_{a g d, t}\right)+F A E_{t}-Y G F A E_{t} \\
& F A E A C C_{t 1}=F A E A C C O \\
& F A E A C C_{t}=F A E_{t-1}+F A E A C C_{t-1}
\end{aligned}
$$

Where:

$Y G F A E_{t}:$ Government interest income from the FAE

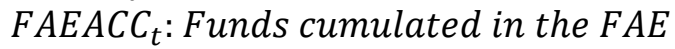

$F A E_{t}:$ Fondo de Ahorro y Estabilizacion

$Y R O W_{t}:$ Rest - of - the - world income

$E X D_{i, t}$ : World demand for exports of product $i$

$T R_{\text {agd,t }}:$ Transfers to domestic agents

FAEACCO: Initial funds accumulated in the FAE

faeintrat: Interest rate for the FAE

faerat $_{t}$ : share of royalties income destined to the FAE 